\title{
MIR31 Gene
}

National Cancer Institute

\section{Source}

National Cancer Institute. MIR31 Gene. NCI Thesaurus. Code C113230.

This gene may play a role in both the regulation of gene expression and tumor suppression. 